\title{
Species-specific associations between overstory and understory tree species in a semideciduous tropical forest
}

\author{
Flaviana Maluf Souza ${ }^{1}$, Sergius Gandolfi ${ }^{2}$ and Ricardo Ribeiro Rodrigues ${ }^{2}$
}

Received: May 20, 2014. Accepted: September 5, 2014

\begin{abstract}
We investigated the occurrence of associations between overstory and understory tree species in a semideciduous tropical forest. We identified and measured all trees of nine canopy species with diameter at breast height $\geq 4.8 \mathrm{~cm}$ in a 10.24 ha plot and recorded all individuals beneath their canopies ("understory individuals") within the same diameter class. The total density of understory individuals did not significantly differ under different overstory species. One overstory species (Ceiba speciosa) showed higher understory species richness compared with five other species. There was a strong positive association between three overstory species (Esenbeckia leiocarpa, Savia dictyocarpa, and C. speciosa) and the density of seven understory species (Balfourodendron riedelianum, Chrysophyllum gonocarpum, E. leiocarpa, Holocalyx balansae, Machaerium stipitatum, Rhaminidium elaeocarpum, and S. dictyocarpa). These results probably reflect the outcome of a complex set of interactions including facilitation and competition, and further studies are necessary to better understand the magnitude and type of the effects of individual overstory species on understory species. The occurrence of species-specific associations shown here reinforces the importance of non-random processes in structuring plant communities and suggest that the influence of overstory species on understory species in high-diversity forests may be more significant than previously thought.
\end{abstract}

Keywords: Environmental heterogeneity, facilitation, plant-plant interaction, rarefaction, species richness

\section{Introduction}

Trees are a major component of forest ecosystems and their interactions with other plants and organisms are assumed to play a fundamental role in structuring forest communities. One of the key factors by which trees influence ecological processes is related to how they regulate environmental heterogeneity as they can create, maintain, or modify biotic and abiotic characteristics across temporal and spatial scales (Jones et al. 1997; Pickett et al. 2000). For instance, trees can influence the light beneath their canopies (Tomita \& Seiwa 2004; Bartemucci et al. 2006; Mejía-Domínguez et al. 2011), the physical and chemical soil properties (Amiotti et al. 2000; Garbin et al. 2006), litter depth (Mejía-Domínguez et al. 2011), as well as the organismal community of the rhizosphere (Watkinson 1998) and the phylosphere (Lambais et al. 2006). According to its characteristics, a species may provide preferential habitats for some organisms more than others, creating selective forces and giving rise to species-specific interactions (Walker \& Vitousek 1991; Tewksbury \& Lloyd 2001; Tecco et al. 2006). Therefore, some canopy species could act as ecological filters "selecting" the species that establish beneath their canopies either through positive or negative associations (George \& Bazzaz 1999a; b; Peters et al. 2004; Tomita \& Seiwa 2004).

There is evidence that the magnitude of the effects that organisms have on one another is influenced by their sizes (Jones et al. 1997; Tewksbury \& Lloyd 2001) and also depends on the amount of time that the conditions responsible for the effects remain present in the environment, i.e., the longer the driving force is present, the larger will be the magnitude of its effects (Jones et al. 1997). Therefore, it can be predicted that overstory trees may significantly influence the structure and species composition of the understory as they occupy a considerable amount of space and remain for dozens or even hundreds of years in the forest. However, in species-rich ecosystems, such as tropical and subtropical forests, there are few studies investigating associations between overstory and understory plants, and much remains to be explored, particularly regarding tree species (Walker \& Vitousek 1991; Vieira et al. 2004; MejíaDomínguez et al. 2011).

Numerous authors have shown that distinct overstory species differentially affect not only the general environment, but also other species, with consequences for the density and species richness underneath their canopies (Tomita \& Seiwa 2004; Wang \& Augspurger 2006; Vivanco \& Austin

\footnotetext{
${ }^{1}$ Forestry Institute, Department of Forest Ecology. Rua do Horto, 931, CEP 02377-000, São Paulo, SP, Brazil. Corresponding author. Email: flavianams@yahoo.com.br ${ }^{2}$ ESALQ/USP, Department of Biological Sciences. Caixa postal 9, CEP 13418-900, Piracicaba, SP, Brazil.
} 
2008; Mejía-Domínguez et al. 2011). The potential for a given species to promote different responses in other species calls attention to the importance of considering species identity in ecological studies to better understand the mechanisms influencing community organization. Here, we investigated the occurrence of species-specific associations between overstory and understory plants and their consequences on the community organization in a semideciduous tropical forest. We assessed the woody plant community beneath nine overstory species to determine the existence of differential responses in the understory plant density and species richness. We addressed the following questions: i) does the total density of understory individuals differ among overstory species? ii) does the understory species richness differ among overstory species? iii) does the density of each of the understory species differ among overstory species?

\section{Methods}

\section{Study site and field survey}

This study was conducted at the Caetetus Ecological Station (EEC) (Gália and Alvinlândia municipalities, São Paulo State, Brazil; $22^{\circ} 41^{\prime}$ S; $49^{\circ} 10^{\prime}$ W), which comprises around 2200 ha of seasonal semideciduous forest (IBGE 2012). The annual rainfall at the site is $1300 \mathrm{~mm}$ and the water deficit occurs between April and September, when $20-50 \%$ of the individuals lose their leaves (IBGE 2012).

The sampling was done in a 10.24 ha permanent plot previously allocated in the central portion of the EEC, where all trees with diameter at breast height $(\mathrm{DBH}) \geq 4.8$ $\mathrm{cm}$ were tagged, measured, and identified. For this study, we selected a subset of the overstory trees (i.e., those which formed the forest canopy) which had at least five individuals in the plot. We excluded palms and all the trees that were bent, broken, or with crowns covered by lianas, as well as the trees inside or at the edge of gaps. We also excluded the pioneer species in the overstory, since their life-cycle is short (Swaine \& Whitmore 1988) and their effects on both young and adult understory trees would most likely be minimal in comparison to late successional species. Underneath the canopy of each overstory tree, we recorded all trees and treelets with $\mathrm{DBH} \geq 4.8 \mathrm{~cm}$ (hereafter referred as "understory individuals"). As the overstory trees had different crown sizes, the sampling area varied according to each overstory individual. To calculate the crown area of the overstory trees and to estimate the density of understory individuals, we took two perpendicular measurements, the first corresponding to the largest crown length (Mueller-Dombois \& Ellenberg 1974).

\section{Data analysis}

To test for differences in the total density of understory individuals beneath the overstory species, we performed a per- mutational (or randomized) analysis of variance (ANOVA), with the overstory species as the independent variable, and the number of levels corresponding to the number of overstory species. As the variances were homogeneous, we used this alternative approach to avoid the inflation of Type I error due to the possible spatial autocorrelation among sampling units (Legendre et al. 1990; Legendre \& Legendre 1998; Dale \& Fortin 2002). We obtained the P-value by running 10,000 permutations with our original data so that an error probability of 0.05 means that in $5 \%$ of the 10,000 permutations the obtained F-value was equal to or higher than the original F-value (Manly 1991). This procedure was conducted with the software R (R Development Core Team 2014).

Since species richness is highly influenced by the abundance of individuals in the sample (Magurran 2004), we used rarefaction curves to test for differences in species richness in the understory. With this technique, we reduced the samples to a common number of individuals, thus controlling for differences in the abundance of understory individuals under each overstory species. For this analysis, we used the "diversity analysis" option in EcoSim 7.0 (Gotelli \& Entsminger 2001), with independent sampling and 1000 iterations. We carried out this procedure several times to estimate the species richness in the understory community under each individual overstory species, performing two-by-two comparisons of the overstory species.

To explore the occurrence of species-specific associations between the overstory and understory species we used correspondence analysis (CA). Among ordination techniques, this is one of the most recommended method for investigating the relationships between species (here, represented as the understory species) and different locations (here, corresponding to the habitat underneath overstory species) (Manly 1994). To avoid distortions caused by species with low abundance, we considered only the understory species that had at least five individuals. We performed the CA using a two-way contingency table containing the overstory species in the rows and the understory species in the columns; the data in each cell represented the density of each understory species beneath each overstory species. We assessed the results of the axes for which the eigenvalues were higher than the expected by the "broken stick" null model (Legendre \& Legendre 1998). The CA was performed with the Fitopac 1.6 software (Shepherd 2006).

\section{Results}

We recorded 138 overstory individuals that corresponded to nine tree species (Table 1). Underneath their canopies, we found 1008 trees distributed among 73 species (Table 2). Only 26 understory species were represented by five or more individuals, corresponding to 925 individuals included in the CA. 
The total density of individuals in the understory did not differ among the nine overstory species (permutational ANOVA: $F=0.402, P=0.918$ ). In general, species richness in the understory did not differ among the overstory species, except for Ceiba speciosa, which showed higher species richness when compared to Senegalia polyphylla, Astronium graveolens, Centrolobium tomentosum, Esenbeckia leiocarpa, and Savia dictyocarpa (Table 3).
The first two ordination axes had values higher than the broken stick model. The cumulative inertia of both axes, which represents the explained variation, was $61.8 \%$. The plotted scores of the overstory species showed that there were three species (E. leiocarpa, S. dictyocarpa, and C. speciosa) that were the most distant from the centroid (the mean of the rows and columns of the matrix), i.e., they were different from the average profile (Fig. 1A). When as-

Table 1. Abundance of the overstory trees and the total density of understory individuals beneath their canopies (mean \pm standard error) in a tropical semideciduous forest in Brazil. There were no significant differences in the density of understory individuals among overstory species (permutational ANOVA, $P<0.05$ ).

\begin{tabular}{|c|c|c|c|c|}
\hline Family & Overstory species & Code & $\begin{array}{l}\text { Number of sampled } \\
\text { individuals }\end{array}$ & $\begin{array}{l}\text { Density of individuals underneath } \\
\text { the canopy (individuals } / \mathrm{m}^{2} \text { ) }\end{array}$ \\
\hline Apocynaceae & Aspidosperma polyneuron Müll.Arg. & Aspo & 50 & $0.155 \pm 0.015$ \\
\hline Rutaceae & Balfourodendron riedelianum (Engl.) Engl. & Bari & 26 & $0.170 \pm 0.019$ \\
\hline Fabaceae & Piptadenia gonoacantha (Mart.) J.F.Macbr. & Pigo & 14 & $0.151 \pm 0.032$ \\
\hline Anacardiaceae & Astronium graveolens Jacq. & Asgr & 10 & $0.127 \pm 0.023$ \\
\hline Rutaceae & Esenbeckia leiocarpa Engl. & Esle & 10 & $0.133 \pm 0.014$ \\
\hline Fabaceae & Centrolobium tomentosum Guillem. ex Benth. & Ceto & 9 & $0.181 \pm 0.021$ \\
\hline Phyllanthaceae & Savia dictyocarpa Müll.Arg. & Sadi & 8 & $0.173 \pm 0.034$ \\
\hline Fabaceae & Senegalia polyphylla (DC.) Britton \& Rose & Sepo & 6 & $0.149 \pm 0.049$ \\
\hline Malvaceae & Ceiba speciosa (A.St.-Hil.) Ravenna & Cesp & 5 & $0.140 \pm 0.029$ \\
\hline
\end{tabular}

Table 2. Understory tree species sampled beneath nine overstory species in a tropical semideciduous forest in Brazil. An asterisk after the species' name indicates abundance $\geq 5$ individuals.

\begin{tabular}{|c|c|c|}
\hline Family & Species & Code \\
\hline Anacardiaceae & Astronium graveolens Jacq. * & Asgr \\
\hline Annonaceae & Annona sylvatica A.St.-Hil. & Ansy \\
\hline Apocynaceae & Aspidosperma polyneuron Müll.Arg. * & Aspo \\
\hline \multirow[t]{2}{*}{ Arecaceae } & Syagrus oleracea (Mart.) Becc. * & Syol \\
\hline & Syagrus romanzoffiana (Cham.) Glassman * & Syro \\
\hline Bignoniaceae & Jacaranda micrantha Cham. & Jami \\
\hline \multirow[t]{4}{*}{ Boraginaceae } & Cordia americana (L.) Gottschling \& J.S.Mill. & Coam \\
\hline & Cordia ecalyculata Vell. & Coec \\
\hline & Cordia superba Cham. & Cosu \\
\hline & Cordia trichotoma (Vell.) Arráb. ex Steud. & Cotr \\
\hline Cardiopteridaceae & Citronella paniculata (Mart.) R.A.Howard & Cipa \\
\hline Caricaceae & Jacaratia spinosa (Aubl.) A.DC. & Jasp \\
\hline Celastraceae & Maytenus gonoclada Mart. & Mago \\
\hline \multirow[t]{3}{*}{ Euphorbiaceae } & Actinostemon concepcionis (Chodat \& Hassl.) Hochr. & Atco \\
\hline & Actinostemon concolor (Spreng.) Müll.Arg. * & Acco \\
\hline & Croton floribundus Spreng. * & Crfl \\
\hline \multirow[t]{7}{*}{ Fabaceae } & Albizia niopoides (Spruce ex Benth.) Burkart & Alni \\
\hline & Albizia polycephala (Benth.) Killip ex Record & Alpo \\
\hline & Bauhinia longifolia D.Dietr. & Balo \\
\hline & Centrolobium tomentosum Guillemin ex Benth. * & Ceto \\
\hline & Inga marginata Willd. & Inma \\
\hline & Inga striata Benth. & Inst \\
\hline & Holocalyx balansae Micheli * & Hoba \\
\hline
\end{tabular}


Table 2. Continuation.

\begin{tabular}{|c|c|c|}
\hline Family & Species & Code \\
\hline & Lonchocarpus cultratus (Vell.) A.M.G.Azevedo \& H.C.Lima & Locu \\
\hline & Machaerium hirtum (Vell.) Stellfeld & Mahi \\
\hline & Machaerium stipitatum Vogel * & Mast \\
\hline & Parapiptadenia rigida (Benth.) Brenan & Pari \\
\hline & Peltophorum dubium (Spreng.) Taub. & Pedu \\
\hline & Piptadenia gonoacantha (Mart.) J.F.Macbr. ${ }^{*}$ & Pigo \\
\hline & Senegalia polyphylla (DC.) Britton \& Rose & Sepo \\
\hline \multirow[t]{2}{*}{ Lauraceae } & Nectandra megapotamica (Spreng.) Mez & Neme \\
\hline & Ocotea prolifera (Nees \& Mart.) Mez ${ }^{*}$ & Ocpr \\
\hline Lecythidaceae & Cariniana estrellensis (Raddi) Kuntze & Caes \\
\hline \multirow[t]{2}{*}{ Malvaceae } & Ceiba speciosa A.St.-Hil. & Cesp \\
\hline & Pseudobombax grandiflorum (Cav.) A. Robyns & Psgr \\
\hline \multirow[t]{4}{*}{ Meliaceae } & Cedrela fissilis Vell. & Cefi \\
\hline & Trichilia catigua A.Juss. * & Trca \\
\hline & Trichilia clausseni C.DC. * & Trcl \\
\hline & Trichilia pallida Sw. ${ }^{*}$ & Trpa \\
\hline Monimiaceae & Mollinedia widgrenii A.DC. & Mowi \\
\hline Moraceae & Ficus sp. & Fisp \\
\hline \multirow[t]{7}{*}{ Myrtaceae } & Campomanesia xanthocarpa (Mart.) O.Berg * & Caxa \\
\hline & Campomanesia guazumifolia (Cambess.) O. Berg & Cagu \\
\hline & Eugenia blastantha (O. Berg) D. Legrand & Eubl \\
\hline & Eugenia florida DC. & Eufl \\
\hline & Eugenia ramboi D.Legrand * & Eura \\
\hline & Neomitranthes glomerata (D.Legrand) D.Legrand * & Negl \\
\hline & Plinia peruviana (Poir.) Govaerts & Plpe \\
\hline \multirow[t]{2}{*}{ Nyctaginaceae } & Guapira hirsuta (Choisy) Lundell & Guhi \\
\hline & Pisonia ambigua Heimerl & Piam \\
\hline Opiliaceae & Agonandra excelsa Griseb. & Agex \\
\hline Phyllanthaceae & Savia dictyocarpa Müll.Arg. * & Sadi \\
\hline \multirow[t]{2}{*}{ Phytolaccaceae } & Gallesia integrifolia (Spreng.) Harms & Gain \\
\hline & Seguieria floribunda Benth. & Sefl \\
\hline Primulaceae & Myrsine umbellata Mart. & Myum \\
\hline \multirow[t]{2}{*}{ Rhamnaceae } & Colubrina glandulosa Perkins & Cogl \\
\hline & Rhamnidium elaeocarpum Reissek * & Rhel \\
\hline Rubiaceae & Ixora venulosa Benth. & Ixve \\
\hline \multirow[t]{6}{*}{ Rutaceae } & Balfourodendron riedelianum (Engl.) Engl. * & Bari \\
\hline & Esenbeckia leiocarpa Engl. * & Esle \\
\hline & Metrodorea nigra A.St.-Hil. * & Meni \\
\hline & Pilocarpus pauciflorus A. St.-Hil. & Pipa \\
\hline & Zanthoxylum caribaeum Lam. & Zaca \\
\hline & Zanthoxylum fagara (L.) Sarg. & Zafa \\
\hline \multirow[t]{3}{*}{ Salicaceae } & Casearia gossypiosperma Briq. ${ }^{*}$ & Cago \\
\hline & Casearia sylvestris Sw. & Casy \\
\hline & Xylosma pseudosalzmanii Sleumer & Xyps \\
\hline \multirow[t]{2}{*}{ Sapindaceae } & Cupania vernalis Cambess. * & Cuve \\
\hline & Diatenopteryx sorbifolia Radlk. * & Diso \\
\hline Sapotaceae & Chrysophyllum gonocarpum (Mart. \& Eichler ex Miq.) Engl. * & Chgo \\
\hline \multirow[t]{2}{*}{ Urticaceae } & Cecropia glaziovii Snethl. & Cegl \\
\hline & Urera baccifera (L.) Gaudich. ex Wedd. & Urba \\
\hline Verbenaceae & Aloysia virgata (Ruiz \& Pav.) Juss. & Alvi \\
\hline
\end{tabular}


Table 3. Mean $(\overline{\mathrm{S}})$ and $95 \%$ confidence interval (CI) of estimated understory species richness underneath overstory species in a two-by-two comparison. The numbers between brackets are the total number of understory individuals and species under the corresponding overstory species, respectively. When the recorded species richness (in brackets) falls within the CI of the species in the rows, there is no significant difference by rarefaction. The overstory species that showed differences in the understory species richness are in bold. Lo-Lower limit of the CI; Up-upper limit of the CI.

\begin{tabular}{|c|c|c|c|c|c|c|c|c|c|c|c|c|c|c|c|c|c|c|c|c|c|c|c|c|}
\hline \multirow[t]{2}{*}{ Overstory species } & \multicolumn{3}{|c|}{$\begin{array}{l}\text { S. polyphylla } \\
\qquad(27 ; 10)\end{array}$} & \multicolumn{3}{|c|}{$\begin{array}{c}\text { S. dictyocarpa } \\
(35 ; 12)\end{array}$} & \multicolumn{3}{|c|}{$\begin{array}{l}\text { E. leiocarpa } \\
\qquad(37 ; 12)\end{array}$} & \multicolumn{3}{|c|}{$\begin{array}{l}\text { C. speciosa } \\
(43 ; 19)\end{array}$} & \multicolumn{3}{|c|}{$\begin{array}{l}\text { A. graveolens } \\
\qquad(60 ; 19)\end{array}$} & \multicolumn{3}{|c|}{$\begin{array}{l}\text { C. tomentosum } \\
\qquad(64 ; 19)\end{array}$} & \multicolumn{3}{|c|}{$\begin{array}{l}\text { P. gonoacantha } \\
\qquad(80 ; 23)\end{array}$} & \multicolumn{3}{|c|}{$\begin{array}{c}\text { B. riedelianum } \\
(200 ; 40)\end{array}$} \\
\hline & $\overline{\mathrm{S}}$ & Lo & Up & $\overline{\mathrm{S}}$ & Lo & Up & $\overline{\mathrm{S}}$ & Lo & Up & $\overline{\mathrm{S}}$ & Lo & Up & $\overline{\mathrm{S}}$ & Lo & Up & $\overline{\mathrm{S}}$ & Lo & Up & $\overline{\mathrm{S}}$ & Lo & Up & $\overline{\mathrm{S}}$ & Lo & Up \\
\hline $\begin{array}{l}\text { Aspidosperma } \\
\text { polyneuron }(462 ; 54)\end{array}$ & 11.7 & 8 & 16 & 14.0 & 10 & 18 & 14.5 & 10 & 19 & 15.8 & 12 & 20 & 19.3 & 14 & 24 & 20.0 & 15 & 25 & 22.4 & 17 & 27 & 36.2 & 31 & 42 \\
\hline $\begin{array}{l}\text { Balfourodendron } \\
\text { riedelianum }\end{array}$ & 12.7 & 9 & 17 & 15.0 & 11 & 19 & 15.7 & 11 & 20 & 17.1 & 13 & 21 & 21.0 & 17 & 25 & 21.6 & 17 & 26 & 24.7 & 20 & 29 & - & - & - \\
\hline $\begin{array}{l}\text { Piptadenia } \\
\text { gonoacantha }\end{array}$ & 12.4 & 9 & 16 & 14.5 & 11 & 18 & 15.1 & 12 & 19 & 16.4 & 13 & 20 & 19.8 & 17 & 22 & 20.5 & 18 & 23 & - & - & - & - & - & - \\
\hline $\begin{array}{l}\text { Centrolobium } \\
\text { tomentosum }\end{array}$ & 12.4 & 10 & 15 & 14.3 & 12 & 17 & 14.9 & 12 & 18 & 15.9 & 13 & 18 & 18.5 & 17 & 19 & - & - & - & - & - & - & - & - & - \\
\hline Astronium graveolens & 11.9 & 9 & 15 & 14.0 & 11 & 17 & 14.4 & 11 & 17 & 15.8 & 13 & 18 & - & - & - & - & - & - & - & - & - & - & - & - \\
\hline Ceiba speciosa & 14.1 & 11 & 17 & 16.6 & 14 & 19 & 17.3 & 15 & 19 & - & - & - & - & - & - & - & - & - & - & - & - & - & - & - \\
\hline Esenbeckia leiocarpa & 10.3 & 8 & 12 & 11.7 & 11 & 12 & - & - & - & - & - & - & - & - & - & - & - & - & - & - & - & - & - & - \\
\hline Savia dictyocarpa & 10.3 & 8 & 12 & - & - & - & - & - & - & - & - & - & - & - & - & - & - & - & - & - & - & - & - & - \\
\hline Senegalia polyphylla & - & - & - & - & - & - & - & - & - & - & - & - & - & - & - & - & - & - & - & - & - & - & - & - \\
\hline
\end{tabular}

sessing both overstory (Fig. 1A) and understory (Fig. 1B) plotted scores, as if they were overlapped, it was possible to visualize that the ordination of these three species was influenced primarily by the density of E. leiocarpa and Holocalyx balansae (underneath E. leiocarpa); Chrysophyllum gonocarpum and S. dictyocarpa (under S. dictyocarpa); and Machaerium stipitatum, Rhaminidium elaeocarpum, and Balfourodendron riedelianum (under C. speciosa). The density of understory individuals of the species $H$. balansae and E. leiocarpa was higher underneath E. leiocarpa overstory trees (Fig. 2). Chrysophyllum gonocarpum and S. dictyocarpa showed higher density under S. dictyocarpa, whereas M. stipitatum, $R$. elaeocarpum, and B. riedelianum had higher density underneath C. speciosa (Fig. 2).

\section{Discussion}

The total density of understory individuals was not affected by any overstory species, which is partially consistent with the findings of Mejía-Domínguez et al. (2011). These authors compared the density of saplings underneath the canopy of four different overstory species and did not find any significant differences between them. However, they did not discuss what factors could be responsible for this pattern, although significant differences were observed in some environmental variables (soil moisture, litter depth, and total solar radiation) under different canopy species. On the other hand, when comparing each canopy species to a mixed-species canopy "control", Mejía-Domínguez et al. (2011) found lower sapling density beneath one of the studied species. Similarly, when comparing the understory of four palm species, Wang \& Augspurger (2006) found that woody seedling density was lower under two of them, although these differences varied according to the specific study site. Dias et al. (2005) found contrasting effects of patches dominated by Clusia hilariana Schltdl. on different size classes of individuals in the understory (seedlings, juveniles, and adults) in comparison to non-Clusia patches. Seedling density was not affected by C. hilariana, whereas the density of juveniles was higher beneath Clusia patches, and the density of adults was lower. According to the authors, the possible factors responsible for the results observed in all of these studies include differences in litter depth, light levels, and seed deposition under the canopies, which could lead to positive or negative effects depending on the considered species.

Although we did not observe any effects of the overstory species on the total density of understory plants, our results suggest the occurrence of species-specific associations between overstory and understory species in terms of community species richness and density of individual understory species. We found that species richness was significantly higher under C. speciosa compared with five other overstory species. A similar finding was reported by Koorem \& Moora (2010) when comparing two species in a spruce-dominated forest. They believe that Corylus avellana had higher species richness beneath its canopies due to the smaller amount of litter it produced, which would be more suitable for seedling development. Cavieres \& Badano (2009) also found higher species richness of plants growing within cushion-plants in several alpine ecosystems and suggested that the main mechanism operating in their study was the amelioration of stressful conditions by the cushionplants, resulting in a positive (facilitative) effect on other 


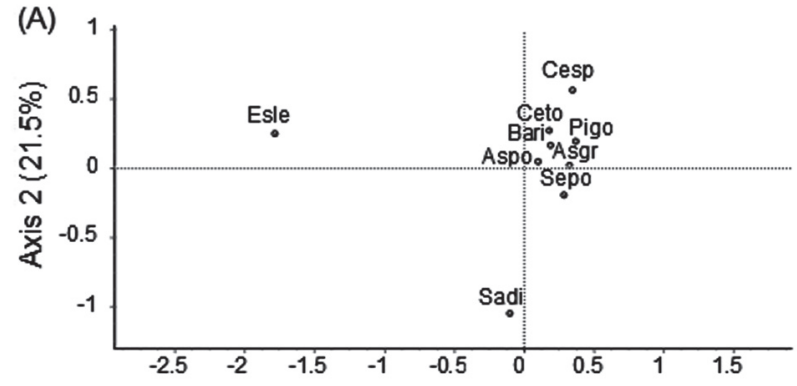

(B)

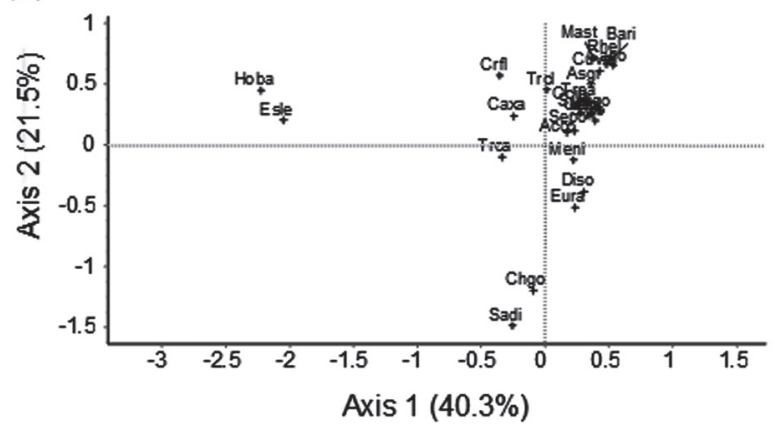

Figure 1. Scores of the overstory (A) and understory (B) species resulting from the Correspondence Analysis between the overstory species and the density of understory individuals underneath their canopies at the Caetetus Ecological Station, São Paulo state, Brazil. The values between brackets correspond to the explained variation in each axis. The codes for the species names are referenced in Tables 1 and 2 .

species. This does not seem to be the case for C. speciosa in the present study as the study site is not a harsh environment; therefore, the occurrence of facilitation through the attenuation of deleterious microenvironmental conditions appears to be unlikely. The architecture of C. speciosa may be a reasonable explanation for the higher species richness in its understory as it is a tall species with a very conspicuous crown, which can make it more attractive to animals which, in turn, can potentially disperse the seeds of other species underneath its canopy. Although C. speciosa is known to possess wind-dispersed seeds (Morellato 1991), there are reports of primates (Olmos et al. 1997) and birds (Willis 2002) feeding from them. Its flowers are big and colorful, which makes them very attractive to the avifauna (Galetti 1993; Willis 2002), and the kapok (silky fibers) is used by many bird species to make their nests (A Z Antunes pers. comm.). Thus, both the primates and birds may excrete or regurgitate previously ingested seeds when visiting $C$. speciosa trees, enhancing the plant species richness underneath their canopies. All the other overstory species have wind- (six species) or ballistic-dispersed (two species) seeds, with no evidence of interactions with frugivorous animals. However, our results do not allow us to safely state that the higher species richness under C. speciosa is the outcome of a positive effect of this species on the understory community.
In addition to the higher species richness under C. speciosa, our results showed evidence of associations between three overstory species and seven understory species, reflected in the different densities of understory species depending on the corresponding overstory species. There are a multitude of factors that may explain different responses of a particular species in the understory, which include either facilitative mechanisms (e.g., "nurse" effects of canopy species) or competition. Among the positive effects, the benefactor may, for example, provide more favorable sites for germination and seedling establishment under their canopies (Tirado \& Pugnaire 2005), amelioration of harmful microenvironmental conditions (Wang et al. 2008; Cavieres $\&$ Badano 2009), and a higher supply of nutrients (Souza et al. 2013), water (Rigg et al. 2002), and light (Tomita \& Seiwa 2004; Souza et al. 2014). Greater seed deposition rates by dispersers (Dias et al. 2005; Duarte et al. 2010) is also an important factor contributing to higher density or species richness under certain species, although this would not be considered true facilitation (Callaway 2007). Competition for abiotic resources (e.g., light, water, nutrients), as reported by many authors, is also an important structuring mechanism in plant communities (Callaway \& Walker 1997; Maestre et al. 2009; Long et al. 2013). Actually, the net effect of one species on another reflects the outcome of multiple positive and negative interactions between them (Callaway 1995; Holmgren et al. 1997; Long et al. 2013; Martorell \& Freckleton 2014), and additional specifically designed studies will be necessary to elucidate these questions.

The substantial differences in plant responses in our study shed light on the debate about the assembly rules in tropical forests. For several decades, ecologists have explained species coexistence and the high diversity of these forests through the "niche partitioning" theory, which hypothesizes that species are specialized for different resources, thus occupying different microenvironments (Penfold \& Lamb 2002; Silvertown 2004). More recently, several authors have been challenging the role of this mechanism to explain species coexistence. Instead, they state that succession is driven by stochastic events (see review in Brokaw \& Busing 2000; Hubbell 2001). The existence of speciesspecific associations suggested by our study reinforces the importance of non-random processes (niche partitioning) in community organization (Duarte et al. 2010; Long et al. 2013) and suggest that the influence of overstory species on understory species in high-diversity forests may be more significant than previously thought.

Our study also highlights the importance of considering the taxonomic identity of overstory species in future studies, as it can provide valuable insights into the causes of the environmental heterogeneity in the understory and its consequences for succession (Mejía-Domínguez et al. 2011). Other aspects of plant-plant associations, such as indirect interactions (Schöb et al. 2013), shifts in the interactions that may occur during the different plant-life phases 
Holocalyx balansae

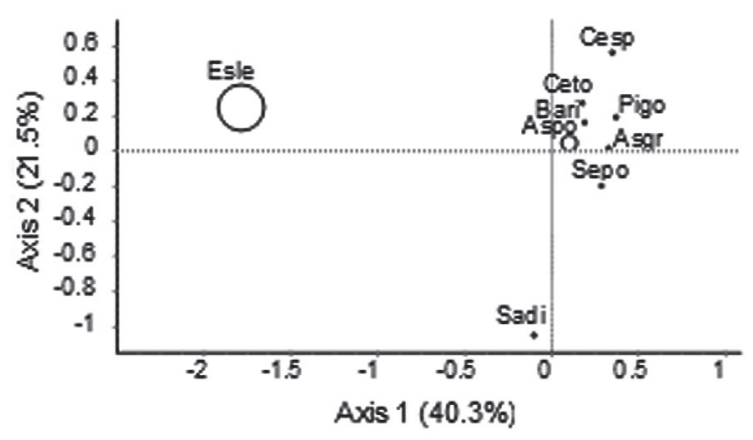

Chryscohyllum gonocaroum

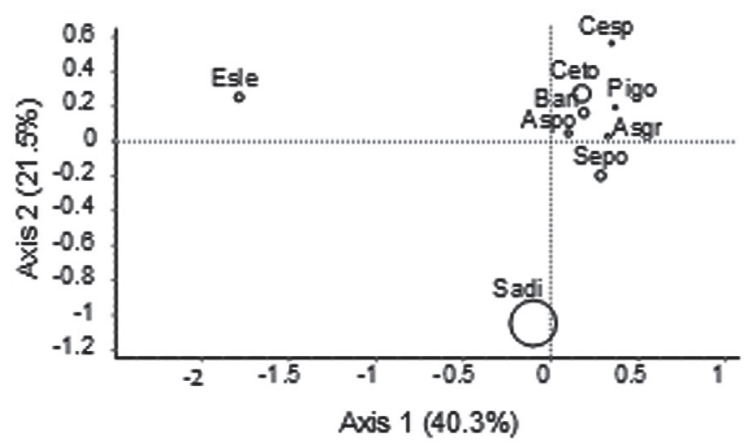

Mecheerium stipitatum

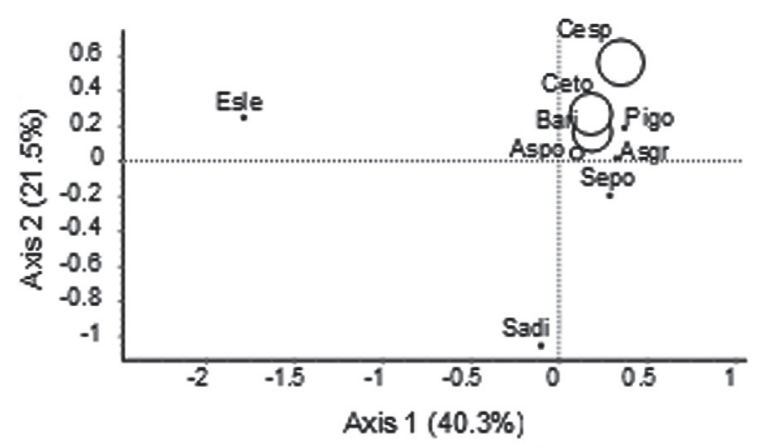

Balfourodendron riedelianum

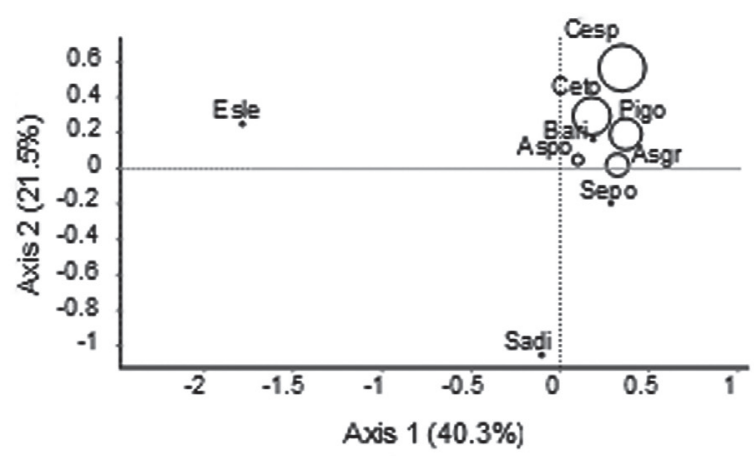

Esenbeckia leiccapa

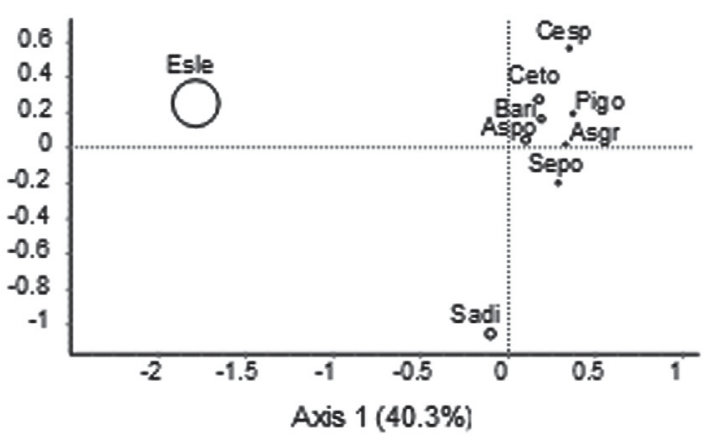

Savia dictyocarpa

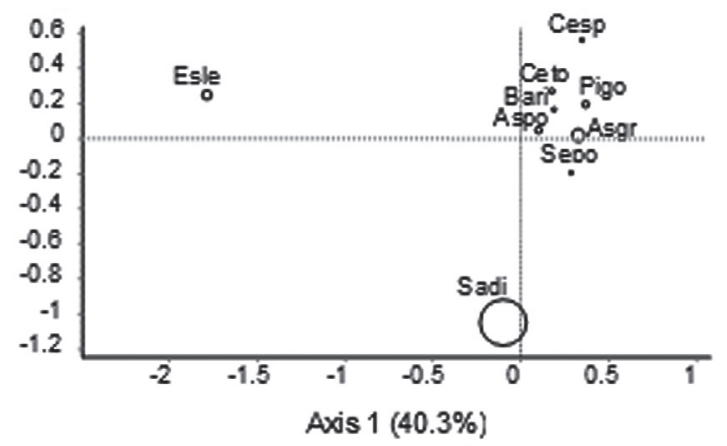

Fhamnidium elaeocaroum

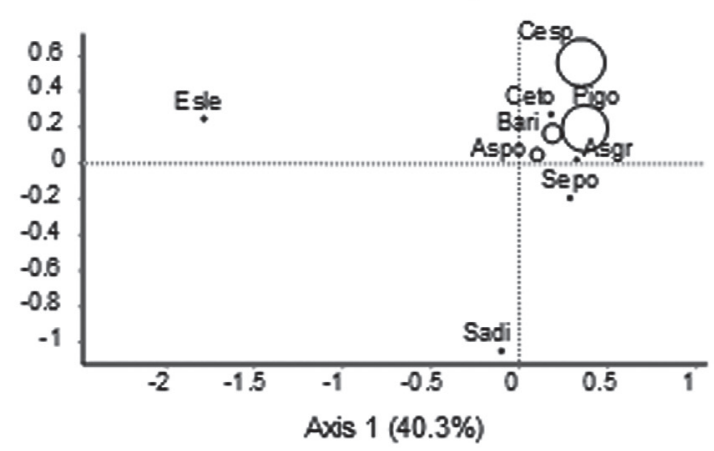

Figure 2. Density of the seven understory species that contributed most to the ordination that resulted from the Correspondence Analysis. The position of each circle corresponds to the scores of the overstory species, and the size of the circle is directly proportional to the density of understory individuals. The codes for the overstory species names are referenced in Table 1. 
(Dias et al. 2005; Roux et al. 2013), above and belowground relationships (Vivanco \& Austin 2008; Montgomery et al. 2010) and effects of multiple species traits (Eviner 2004; Méndez-Toribio et al. 2014) should also be considered when investigating species-rich ecosystems. The increased knowledge concerning the complex set of interactions between species in tropical forests will not only substantially improve our comprehension of the dynamics of speciesrich communities, but can also serve as a powerful tool for ecological restoration projects, since the patterns of occurrence and spatial distribution of plants appear to be strongly influenced by their neighbors (George \& Bazzaz 1999a; Gomez-Aparicio 2009; Montgomery et al. 2010), thus playing a crucial role in restoration success.

\section{Acknowledgments}

We thank FAPESP (grant \#1999/09635-0) and CNPq (grant \#140555/2001-3) for financial support and Idea Wild for the donation of field equipment. We are also very grateful to George Shepherd and Natashi Pilon for the invaluable help with the statistical analyses, and all the people who helped in the fieldwork.

\section{References}

Amiotti NM, Zalba P, Sánchez LF, Peinemann N. 2000. The impact of single-trees on properties of loess-derived grassland soils in Argentina. Ecology 81: 3283-3290.

Bartemucci P, Messier C, Canham CD. 2006. Overstory influences on light attenuation patterns and understory plant community diversity and composition in southern boreal forests of Quebec. Canadian Journal of Forest Research 36: 2065-2079.

Brokaw N, Busing RT. 2000. Niche versus chance and tree diversity in forest gaps. Trends in Ecology and Evolution 15: 183-188.

Callaway RM. 1995. Positive interactions among plants. The Botanical Review 61: 306-349.

Callaway RM. 2007. Positive Interactions and Interdependence in Plant Communities. Dordrecht, Springer.

Callaway RM, Walker LR. 1997. Competition and facilitation: a synthetic approach to interactions in plant communities. Ecology 78: 1958-1965.

Cavieres LA, Badano EI. 2009. Do facilitative interactions increase species richness at the entire community level? Journal of Ecology 97: 1181-1191.

Dale MRT, Fortin MJ. 2002. Spatial autocorrelation and statistical tests in ecology. Ecoscience 9: 162-167.

Dias ATC, Zaluar HLT, Ganade G, Scarano FR. 2005. Canopy composition influencing plant patch dynamics in a Brazilian sandy coastal plain. Journal of Tropical Ecology 21: 343-347.

Duarte LS, Hofmann GS, Santos MMG, Hartz SM, Pillar VD. 2010. Testing for the influence of niche and neutral factors on sapling community assembly beneath isolated woody plants in grasslands. Journal of Vegetation Science 21: 462-471.

Eviner VT. 2004. Plant traits that influence ecosystem processes vary independently among species. Ecology 85: 2215-2229.

Galetti M. 1993. Diet of the scaly-headed parrot (Pionus maximiliani) in a semideciduous forest in southeastern Brazil. Biotropica 25: 419-425.

Garbin ML, Zandavalli RB, Dillenburg LR. 2006. Soil patches of inorganic nitrogen in subtropical Brazilian plant communities with Araucaria angustifolia. Plant and Soil 286: 323-337.
George LO, Bazzaz FA. 1999a. The fern understory as an ecological filter: emergence and establishment of canopy-tree seedlings. Ecology 80: 833-845.

George LO, Bazzaz FA. 1999b. The fern understory as an ecological filter: growth and survival of canopy-tree seedlings. Ecology 80: 846-856.

Gomez-Aparicio L. 2009. The role of plant interactions in the restoration of degraded ecosystems: a meta-analysis across life-forms and ecosystems. Journal of Ecology 97: 1202-1214.

Gotelli NJ, Entsminger GL. 2001. EcoSim: Null models software for ecology. Version 7.0.

Holmgren M, Scheffer M, Huston MA. 1997. The interplay of facilitation and competition in plant communities. Ecology 78: 1966-1975.

Hubbell SP. 2001. The Unified Neutral Theory of Biodiversity and Biogeography. Princeton, Princeton University Press.

IBGE - Istituto Brasileiro de geografia e Estatística. 2012. Manual técnico da vegetação brasileira. Sistema fitogeográfico, inventário das formações vegetais e campestres, técnicas de manejo de coleções botânicas, procedimentos para mapeamentos. Rio de Janeiro, IBGE.

Jones CG, Lawton JH, Shachak M. 1997. Positive and negative effects of organisms as physical ecosystem engineers. Ecology 78: 1946-1957.

Koorem K, Moora M. 2010. Positive association between understory species richness and a dominant shrub species (Corylus avellana) in a boreonemoral spruce forest. Forest Ecology and Management 260: 1407-1413.

Lambais MR, Crowley DE, Cury J, Büll RC, Rodrigues RR. 2006. Bacterial diversity in tree canopies of the Atlantic Forest. Science 312: 1917.

Legendre P, Legendre L. 1998. Numerical Ecology. Amsterdan, Elsevier Science B.V.

Legendre P, Oden NL, Sokal RR, Vaudor A, Kim J. 1990. Approximate analysis of variance of spatially autocorrelated regional data. Journal of Classification 7: 53-75.

Long W, Zang R, Ding Y, Huang Y. 2013. Effects of competition and facilitation on species assemblage in two types of tropical cloud forest. PLoS One 8: e60252.

Maestre FT, Callaway RM, Valladares F, Lortie CJ. 2009. Refining the stress-gradient hypothesis for competition and facilitation in plant communities. Journal of Ecology 97: 199-205.

Magurran AE. 2004. Measuring biological diversity. Malden, Blackwell Publishing.

Manly BFJ. 1991. Randomization and Monte Carlo methods in biology. London, Chapman \& Hall.

Manly B.J. 1994. Multivariate statistical methods - A primer. London, Chapman \& Hall.

Martorell C, Freckleton RP. 2014. Testing the roles of competition, facilitation and stochasticity on community structure in a species-rich assemblage. Journal of Ecology 102: 74-85.

Mejía-Domínguez NR, Meave JA, Díaz-Avalos C, González E.. 2011. Individual canopy-tree species effects on their immediate understory microsite and sapling community dynamics. Biotropica 43: 572-581.

Méndez-Toribio M, González-Di Pierro AM, Quesada M, Benítez-Malvido J. 2014. Regeneration beneath a dioecious tree species (Spondias purpurea) in a Mexican tropical dry forest. Journal of Tropical Ecology 30: 265-268.

Montgomery RA; Reich PB, Palik BJ. 2010. Untangling positive and negative biotic interactions: views from above and below ground in a forest ecosystem. Ecology 91: 3641-3655.

Morellato LPC. 1991. Estudo da fenologia de árvores, arbustos e lianas de uma floresta semidecídua no sudeste do Brasil (Campinas, SP). PhD thesis, UNICAMP, Brazil.

Mueller-Dombois D, Ellenberg H. 1974. Aims and methods of vegetation ecology. New York, Wiley.

Olmos F, Franco GADC, Auricchio P. 1997. Biometry and stomach contents of some Atlantic Forest primates, with a note on Brachyteles tooth replacement. Neotropical primates 5: 36-39.

Penfold GC, Lamb D. 2002. A test of the hypothesis of ecological equivalence in an Australian subtropical rain forest. Journal of Tropical Ecology 18: 327-352.

Peters HA, Pauw A, Silman MR, Terborgh JW. 2004. Falling palm fronds structure Amazonian rainforest sapling communities. Proceedings of the Royal Society of London Series B-Biological Sciences 271: 367-369. 
Pickett STA, Cadenasso ML, Jones CG. 2000. Generation of heterogeneity by organisms: creation, maintenance and transformation. In: Hutchings MJ, John EA, Stewart AJA. (eds.) The ecological consequences of environmental heterogeneity. Oxford, Blackwell Science Ltd. p. 33-52.

R Core Team. 2014. R: A language and environment for statistical computing. R Foundation for Statistical Computing, Vienna, Austria. http://www.R-project.org/.Rigg LS, Enright NJ, Perry GLW, Miller BP. 2002. The role of cloud combing and shading by isolated trees in the succession from maquis to rain forest in New Caledonia. Biotropica 34: 199-210.

Roux PC, Shaw JD, Chown L. 2013. Ontogenetic shifts in plant interactions vary with environmental severity and affect population structure. New Phytologist 200: 241-250.

Schöb C, Armas C, Pugnaire FI. 2013. Direct and indirect interactions co-determine species composition in nurse plant systems. Oikos 122: 1371-1379.

Shepherd GJ. 2006. Fitopac 1.6. Campinas, UNICAMP, Instituto de Biologia, Departamento de Botânica.

Silvertown J. 2004. Plant coexistence and the niche. Trends in Ecology and Evolution 19: 605-611.

Souza FM, Franco GADC, Callaway RM. 2013. Strong distance-dependent effects for a spatially aggregated tropical species. Plant Ecology 214: 545-55.

Souza FM, Gandolfi S, Rodrigues RR. 2014. Deciduousness influences the understory community in a semideciduous tropical forest. Biotropica 46: 512-515.

Swaine MD, Whitmore TC. 1988. On the definition of ecological species groups in tropical rain forests. Vegetatio 75: 81-86.
Tecco PA, Gurvich DE, Díaz S, Pérez-Harguindeguy N, Cabido M. 2006. Positive interaction between invasive plants: The influence of Pyracantha angustifolia on the recruitment of native and exotic woody species. Austral Ecology 31: 293-300.

Tewksbury JJ, Lloyd JD. 2001. Positive interactions under nurse-plants: spatial scale, stress gradients and benefactor size. Oecologia 127: 425-434.

Tirado R, Pugnaire FI. 2005. Community structure and positive interactions in constraining environments. Oikos 111: 437-444.

Tomita M, Seiwa K. 2004. The influence of canopy tree phenology on understorey populations of Fagus crenata. Journal of Vegetation Science 15: 379-388.

Vieira ICG, Uhl C, Nepstad D. 1994. The role of the shrub Cordia multispicata Cham. as a "succession facilitator" in an abandoned pasture, Paragominas, Amazônia. Vegetatio 115: 91-99.

Vivanco L, Austin AT. 2008. Tree species identity alters forest litter decomposition through long-term plant and soil interactions in Patagonia, Argentina. Journal of Ecology 96: 727-736.

Walker LR, Vitousek PM. 1991. An invader alters germination and growth of a native dominant tree in Hawaii. Ecology 72: 1449-1455.

Wang Y, Augspurger C. 2006. Comparison of seedling recruitment under arborescent palms in two Neotropical forests. Oecologia 147: 533-545.

Wang Y, Chua C, Maestre FT, Wang G. 2008. On the relevance of facilitation in alpine meadow communities: An experimental assessment with multiple species differing in their ecological optimum. Acta Oecologica 33: 108-113.

Watkinson AR. 1998. The role of the soil community in plant population dynamics. Trends in Ecology and Evolution 13: 171-172.

Willis EO. 2002. Birds at Eucalyptus and other flowers in Southern Brazil: a review. Ararajuba 10: 43-66. 